\title{
Indicators of sustainability applied to interior design: rethinking the IDSRS model
}

\author{
Ana Carolina de Lima Sarmento ${ }^{1,}$, Paulo Fernando de Almeida Souza ${ }^{1}$ \\ ${ }^{1}$ Federal University of Bahia, School of Fine Arts, R. Araújo Pinho 212, Canela, Salvador-Bahia-Brazil, 40110-150
}

\begin{abstract}
Interiors reveal not only a single space but also a psichological environment involving values, gestures and meanings. In this sense, anticipating environmental impacts of interior design and better adequating sustainability patterns of implementation and use of environments is seen as great relevance in order to achieve quality in regards sustainable development. This paper is written in a descriptive perspective, i.e. exploratory research, presenting the set of indicators of sustainability applied to interior design taking into consideration the Indicators of Design and Social Responsibility - IDSRS model. The main contribution of this study is to reflect on the way interior design is performed from the very beginning of the project, until a post construction and use phase of design involving recycling and reuse strategies. The paper is useful to both practitioners and academics in the fields of indicators of sustainability, particularly applied to interior design.
\end{abstract}

Keywords. Interior Design, Indicators of Sustainability, IDSRS Model.

\section{Introduction}

Sustainability involves relationship between social, economical, and ecological systems in a dynamic process in which life itself can vigorously continue, individuals can prosper socially and economically, human culture can develop in an adequate pace, and, overall, the results of human activities follow limits in a way that ecosystems that support life can diverse and evolve without jeopardizing future generations (SACHS, 1993). Such a challenge can only be effective if several interests can be balanced, e.g. economical, social, ecological, and institutional.

According to Hodge et al. (1999), indicators of sustainability are typically measureable signs that might reflect a quantitative or qualitative characteristic of vital importance in order to identify present, past and future conditions of work of a determined system. The adoption of a set of indicators might be used to determine the quality of a system, its history, interests, needs, goals, and trends. In this sense, to create a set of measures for a system means to value it, to define its best conditions, to qualify and to quantify its characteristics, and, at last to assume control on its behaviours. Therefore, indicators are important tools to make decisions in a complex world.

The aim of this research is to present indicators of sustainability applied to Interior Design, taking into consideration the model of indicators called IDSRS, acronym in Portuguese for Indicators of Design for Sustainability and Social Responsibility (Souza, 2007), developed initially for product design and adapted to
Interior Design (Sarmento e Souza, 2016). The use of this model allows decision makers to evaluate social, environmental and economical impacts of design at the very first stages of its implementation throughout a measure of adequacy in regard of sustainable and socially responsible practices within the design process. The paper is useful to both practitioners and academics in the fields of indicators of sustainability, particularly applied to interior design.

\section{Methodology}

This paper is written in a descriptive perspective, i.e. exploratory research, presenting the set of indicators of sustainability applied to interior design taking into consideration the IDSRS model. It is assumed that the social reality is historically built on and produced or reproduced by people (MYERS, 1997). On the other hand, qualitative analysis was used as support for the development of the method itself, including the kind of knowledge related to the understanding of sustainability phenomena.

Moreover, ground theory (GLASER and STRAUSS, 1967) was used to define parameters to better visualize results during design phases. Shortly, the ground theory method consists of: 1) precise definition of research field and nature; 2) data collection and analyses; 3 ) ordering of data according to relevant criteria; 4) coding, classifying and comparing results to other similar studies around the research itself; 5) generation of theory and/or presentation of a model. During the adaptation of the

a Corresponding author: carol_sarmento@hotmail.com 
IDSRS to interior design a case study was performed in a residential house in order to verify the set of indicators proposed to be used during the design phases. In this paper, we only present the set of indicators itself, trying to demonstrate its use and advantage for the decision making process related to interior design.

\section{The use of IDSRS model}

The IDSRS model has its main reflection on the use of matters, energy and other necessary resources used during the life cycle of products, according to four dimensions of use, as follows: a) quality; b) efficiency; c) sufficiency; and d) equity.

The concept of quality associated to the use of resources will define a certain degree of impact on productive system dynamics, largely influencing project decisions during the whole life cycle of products. On the other hand, the concept of efficiency in use of matters and energy for production is related to a certain capacity of interaction between the system itself and its ideal conditions of functioning, determining for instance the way a process can be improved in order to fit some sustainability patterns. Sufficiency in use regards to aspects of quantities of resources needed to self-regulate the productive system's activity, without endangering its own viability or surrounding environments (ecological and social environments). Finally, the concept of equity brings to decision making some aspects of justice and ethics when dealing with universal principles of harmony.

A set of indicators of sustainability is presented, based on this theoretical model, considering its implementation in four design phases, as follows: 1) production/manufacture; 2) consumption/use/service; 3) discard/deposition; and 4) recycling/reuse/redesign. Five indicators were posted for each correspondent phase of design process, as follows:

a. Production/manufacture: Demand of energy, Diversity of materials, Degree of toxicity, Normalization, Packaging;

b. Consumption/use/service: Conformity to law and regulation, Impacts of use, Demand of energy in use, Multi-functional use, Well-being;

c. Discard/deposition: Garbage discard, Recycling of matters, Disassembling, Code of ethics, Anticipation;

d. Recycling/reuse/redesign: Reuse, Upgrading, Recognizing of materials, Redesign, Reselling/redistribution.

Information is acquired throughout several surveys and interviews with managers, engineers, designers, and decision makers involved in productive system, trying to better diagnose adequacies in regards to sustainable and socially responsible practices, particularly in design phases.

\section{The IDSRS model applied to interior design}

Interior design is defined by Brooker and Stone (2014, p.11) as "any type of interior design project, from decoration to renovation. It is the art of decorating interior spaces - rooms or environments - to convey a characteristic identity that works well with the existing architecture." So, we can understand it as a possibility to transform the geometry of a space into an environment that is rich in emotions, senses and memories that reveal the identity of its users.

Focusing on sustainable projects that go beyond the specification of an ecologically correct product, the adapted IDSRS indicator model was used, aiming to anticipate environmental impacts through sustainability parameters that contribute to the transformation of interior design practice. In principle, the IDSRS model was redesigned for use in interior design, with the addition of the pre-project phase, because it is believed that some details are important and guiding the design of a sustainable project.

Phase I of the adapted IDSRS model, the Preproject, evaluates the land property / space even before the project design itself, that is, we evaluate the accessibility to services and public transportation and the discomfort of the surrounding environment, (Table 1). It is believed that these phase I indicators should be taken into account by directly interfering with the design phase (Phase II).

Table 1. Indicators of sustainability proposed to Interior Design's Pre-project phase.

\begin{tabular}{|c|c|}
\hline $\begin{array}{c}\text { Interior Design } \\
\text { Phase }\end{array}$ & \multicolumn{1}{c|}{ Indicators } \\
\hline I- Pre-project & $\begin{array}{l}\text { - Adequacy of land property } \\
\text { - Public transportation service } \\
\text { - Environmental comfort }\end{array}$ \\
\hline
\end{tabular}

When choosing a land property, house or apartment is there a concern related to the surroundings? In this step we present the indicators that will evaluate if there is soil contamination, if there is flexibility in the services and alternative means of transport, such as, the access to supermarkets, pharmacies, banks and schools.

Some places present environmental discomfort factors that can pose serious health risks to the inhabitants, regardless of whether they are acoustic, olfactory and/or electromagnetic. So, it is possible to measure these factors through a study of the existing surrounding environment. The indicator Environmental Comfort of this first phase checks the levels of sound waves, electromagnetic waves, the incidence of natural lighting and ventilation, as well as the air quality.

Phase II, defined as the Project phase, will assess, for example, solar orientation, accessibility, environmental comfort, water and energy savings, construction flexibility for future interventions, current and future accessibility and mobility of Customers, as well as compliance with legislation and preservation of existing vegetation and buildings. It is the guiding phase of the 
project and, therefore, of great relevance. In this phase we highlight the importance of the interior designer for the definition of the project layout, taking the architectural design as the starting point. Considering this, the other projects that need to be completed in order to start the work are defined, like the the hydraulic, the lighting or the electrical project.

At this stage the professionals' creation process is observed, starting from the list of needs, preliminary studies and technical plants developed. It should be noted that this project design process is linked to the terrain conditions and the environmental perception of those involved in the creation.

Table 2. Indicators of sustainability proposed to Interior Design's Project phase.

\begin{tabular}{|c|l|}
\hline $\begin{array}{c}\text { Interior Design } \\
\text { Phase }\end{array}$ & \multicolumn{1}{c|}{ Indicators } \\
\hline & • Environmental comfort \\
& - Native vegetation preservation \\
& - Flexibility of \\
construction/building \\
II - Project & - Accessibility \\
& - Material specification \\
& - Use of water and energy \\
& - Legal adequacy \\
\hline
\end{tabular}

In addition, phase II evaluates the use of the solar chart for the study of environmental comfort related to environmental performance. It evaluates the acoustics, lighting and natural ventilation of the proposed project, without disregarding the use of the environmentally appropriate artificial climate, when necessary.

At this stage, it is also considered necessary to assess whether the project has preserved existing vegetation and construction, or whether there has been a need to demolish to build and/or to deforest to replant because of project needs. Preserving the existing vegetation and/or construction decreases the amount of waste thrown into the environment and consequently less environmental impacts are generated.

The detailed specification of the materials used in the construction work is of paramount importance when it is desired to reduce the environmental impacts. This indicator is generally the most used when we talk about sustainability in interior design. For example, the local raw materials, their origin, the socio-environmental responsibility of the manufacturers, the saving of water and energy, as well as their toxicity, their ease of maintenance, sorting, disposal and recycling, all these are considered.

Regarding legislation compliance, an indicator is proposed to verify that the project is within the standards and rules required by the main local, regional, and federal oversight agencies.

Phase III, Implementation/Execution, will evaluate the choice of materials, the preparation of the construction site, the saving of water and energy during construction, communication among those involved in the project, the toxicity level of the construction, as well as the complainace with the law. At this stage, there is a tendency to generate more environmental impacts, since it corresponds to the execution phase of what was projected. Therefore we emphasize the importance of the previous phase to guide the others. Table 3 shows the indicators that evaluate this stage of work.

Table 3. Indicators of sustainability proposed to Interior Design's Implementation phase.

\begin{tabular}{|c|l|}
\hline $\begin{array}{c}\text { Interior Design } \\
\text { Phase }\end{array}$ & \multicolumn{1}{c|}{ Indicators } \\
\hline & - Project management \\
& - Communication \\
III - & $\begin{array}{l}\text { - Adequacy of materials } \\
\text { - Toxicity degree } \\
\text { Implementation }\end{array}$ \\
& - Rational use of water and energy \\
& - Legal adequacy \\
\hline
\end{tabular}

Project management is fundamental for the implementation/execution phase of the project, as it ensures that construction will take place on time, it reduces costs, increases quality, reduces problem rates and consequently, it also reduces waste. In this indicator we will consider the valuation of the local workforce, the construction site, the socio-environmental responsibility of the company that will execute the project, among other factors that involve the project management.

A properly managed construction work requires overly specified projects, so communication among stakeholders is of fundamental importance. This indicator proposes to evaluate the ways of communication between them and if the projects were always updated during their execution.

The suitability of materials is related to the execution of the specified materials, and besides evaluating if they are appropriate to the region climate, we will also evaluate how they were installed and if this installation facilitates their removal. At this stage we stress the importance of always having a spare of materials, in case there is a future need for some more.

We currently have products on the market that have a high level of toxicity, such as solvent-based paints with high VOC content - Volatile Organic Compounds. These products are highly harmful to health and therefore they need to be avoided. In this indicator we will evaluate the impact related to toxicity during the process of implementation/execution of the construction work. We will identify the emission of gases, generation of waste and releases of effluents, as well as toxic and harmful materials to health.

It is important to emphasize that, in addition to the specifications of materials and products that favor saving, we must also make rational use of them during the process of implementation and execution of the construction work. For this purpose, this indicator proposes to evaluate the energy demand during this phase and the rationing of water by the professionals involved in the project, both for personal use and for renovation/construction.

At this stage it is also verified whether the project is within the standards and rules required by the main local, regional and federal inspection agencies, regarding 
issues related to environmental protection during the execution phase.

Phase IV, Use and Service, concerns the environment already built. It evaluates the facility for maintenance, water saving and energy consumption of the specified products, as well as the use of automation and the wellbeing of its users. At this stage, an adequate evaluation will only be possible after the the environment has been occupied, since we will need to observe if the occupants of the space were sensitive about the environment use, because, as Papanek (1995, p. 14) said, 'a designer is and always has been a teacher, too, in a position to inform and influence the client [or user-consumer]'. How are these environments being used? Have its occupants been made aware of the environmental issues that were presented in the other stages? Understanding and disseminating the value of a sustainable practice is the basic strategy for the beginning of a broader environmental perception that is really capable of providing new ways of life.

In the Use/Service phase we will evaluate aspects that range from the ease of maintenance, water and energy saving to the multifunctionality of spaces and the well-being that the environment offers after it has been occupied.

Table 4. Indicators of sustainability proposed to Interior Design's Use/service phase.

\begin{tabular}{|c|c|}
\hline $\begin{array}{c}\text { Interior Design } \\
\text { Phase }\end{array}$ & Indicators \\
\hline IV - Use/service & $\begin{array}{l}\text { - Easy maintenance } \\
\text { - Automation in use } \\
\text { - Well being } \\
\text { - Rational use of water and energy } \\
\text { - Multifunctionality } \\
\text { - Legal adequacy }\end{array}$ \\
\hline
\end{tabular}

Ease of maintenance is an important factor when long-term lifetime is desired for the environment, regardless of whether it will undergo interventions over the years. Designing to make it easier to use makes the environment more sustainable. This indicator proposes the identification of factors that facilitate the maintenance of the environment, such as the choice of materials, accessibility to electrical and hydraulic points and the service of technical assistance offered by suppliers.

Regarding automation, we will check if its use was considered from the earliest stages of the project, whether structural interventions were necessary to adapt it or whether wireless networks were used, as well as its contribution as a sustainable tool for water and energy saving

The Well-being indicator proposes to identify if the use of the environment generates some type of risk to the users, such as electric shock, contamination, injuries, as well as their impacts attributed to misuse. We will check if the environment generates some kind of toxic matter, the solid waste amounts and the degree of pollutants emission. In this phase, the consumption of water and energy and the energetic consumption of appliances such as air conditioning, dishwashers, crushers, etc., are also evaluated.

The criterion of multifunctionality of the built environment admits the diversification of use, acceptability of space and consequently, better coexistence among users. Environments that have this usability optimization have a longer lifetime. This indicator identifies the extent to which environments have been designed to meet ephemeral needs, when necessary.

At this stage, compliance with legislation concerns the use of the environment already built. In cases where renovations are needed, are there rules for this implementation? What impacts do these changes have on the environment? It is necessary to evaluate if there is an internal charter that ensures these changes with safety, and if it is being fulfilled.

Finally, the last phase of the adapted model, Disposal/Recycling/Reuse, is related to construction residues, their waste disposal and reuse, as well as to the ease of recognition of materials used (Table 5). The destination of the construction work residue is evaluated, as are its losses and, above all, we check if there was reuse, disposal and the appropriate treatment of the organic and non-organic materials. In order to do so, we observe the existence and functioning of systems for residue selection, collection and disposal during the execution and use of the built environment.

Table 5. Indicators of sustainability proposed to Interior Design's Disposal/recycling/reuse phase.

\begin{tabular}{|c|l|}
\hline $\begin{array}{c}\text { Interior Design } \\
\text { Phase }\end{array}$ & \multicolumn{1}{c|}{ Indicators } \\
\hline & $\begin{array}{l}\text { • Residues management } \\
\text { - Disposal of matters }\end{array}$ \\
V-Disposal/ & $\begin{array}{l}\text { - Easy disassembly } \\
\text { Recycling/Reuse }\end{array}$ \\
& $\begin{array}{l}\text { - Legal adequacy } \\
\text { Easy recycling/reuse of matters }\end{array}$ \\
\hline
\end{tabular}

In addition, the ease of disassembly allows an optimization in the process of recycling and reuse of materials besides facilitating the deposition and disposal process. In this indicator we evaluate whether the materials and products used facilitate reuse and recycling and if recycled raw materials were used.

Another evaluated indicator relates to multidisciplinarity in the search for solutions among those involved in the perspective of civil construction, for example.

\section{Final considerations}

Following Papanek's (1995) teachings, when we think of environments designed in a harmonious way with the people who will live there, we reflect sustainability and consequently, we contribute to sustainable development. Although it is challenging, we need to evolve in the relationship between society and the environment, so that we have harmony between both. It is necessary to rethink ways of experiencing daily life 
interacting with nature and generating less impact to the environment.

Sustainability in interior design is often associated only with environmentally responsible products. The main contribution of this study is to reflect on the way interior design is performed from the very beginning of the project, until a post construction and use phase of design involving recycling and reuse strategies. Just like Papanek (1995) used to say, Moxon (2012) also emphasizes that sustainable projects should not be optional, but rather introducing the practice of a quality project, since the concern for sustainability should be applied as a mandatory requirement for any design project.

The use of sustainability indicators should be understood as a strategic tool that proposes new ways of designing, based on a project methodology that allows an anticipation of environmental impacts. We chose to investigate the case from the earliest stages of the project, to evaluate the intended impacts prior to their realization. The use of indicators enables proper decision-making in all stages of construction, adapting it to the parameters of sustainability and consequently, reducing socio-environmental impacts.

\section{Acknowledgments}

We appreciate the support of Fundação de Amparo a Pesquisa do Estado da Bahia - FAPESB, for granting Ana Sarmento the master's degree scholarship in the period 2015-2017.

\section{References}

BROOKER, G.; STONE, S. O que é design de interiores? São Paulo: Editora Senac São Paulo, 2014.

GLASER, Barney G. e STRAUSS, Anselm L. The Discovery of Grounded Theory. Chicago: Aldine de Gruyter, 1967.

HODGE, R. Anthony; HARDI, Peter e BELL, David. Seeing change through the lens of sustainability. Costa Rica: The International Institute for Sustainable Development - IISD, 1999.

MOXON, S. Sustentabilidade no design de Interiores. Amadora: Editorial Gustavo Gili, SL, 2012.

MYERS, Michael D. Qualitative Research in Information Systems. MIS Quarterly, 1997.

PAPANEK, V. Arquitectura e Design. Ecologia e ética. Lisboa: Edição 70, 1995.

SACHS, Ignacy. Estratégias de transição para o século XXI: desenvolvimento e meio ambiente. São Paulo: Studio Nobel/FUNDAP, 1993.

SARMENTO, A. C. L.; SOUZA, P. F. A. Indicadores de Sustentabilidade aplicados ao design de interiores: Análise do modelo IDSRS, In: Anais do $12^{\circ}$ Congresso Brasileiro de Pesquisa e Desenvolvimento em Design, Blucher Design Proceedings, 2016, p. 1885-1893.

SOUZA, P. F. de A. Sustentabilidade $e$ Responsabilidade Social no design do produto: rumo à definição de indicadores. 2007. 294 f. Tese de Doutorado - Faculdade de Arquitetura e Urbanismo, Universidade de São Paulo, São Paulo, 2007. 